\title{
STANDARD BARIUM SULPHATE SUSPENSIONS
}

\author{
BY \\ J. F. BOYD* AND J. W. SOMMERVILLE \\ From the Research Department, Royal Maternity and Women's Hospital, Rottenrow, Glasgow \\ (RECEIVED FOR PUBLICATION JULY 10, 1959)

\begin{abstract}
It has been shown that the state of the volumetric flask, the order of mixing the reagents, and the temperature of the reaction are important influences on the optical density readings of standard barium sulphate suspensions. The rate of mixing the reagents does not appear to be important.

A reproducible method for preparing a standard barium sulphate suspension with an optical density equivalent to $100 \mathrm{mg}$. protein per $100 \mathrm{ml}$. is described.
\end{abstract}

Standard barium sulphate suspensions have been used as standard opacities for (1) Maclagan's vmol turbidity test (1944) by Shank and Hogland (1946) and Ley, Lewis, and Davidson (1946); (2) the zinc sulphate test described by Kunkel (1947); and (3) for the rapid fibrinogen test of Stirland (1956). Maclagan (1951) and Varley (1958), however, have experienced difficulty in reproducing the opacities of these suspensions, as has Ducci (1947), who first pointed out that a misprint in the article of Shank and Hoagland (1946) had caused the ensuing workers to use a $1 \%$ barium chloride solution $(0.0962 \mathrm{~N})$ instead of a $2 \%$ solution $(0.0962 \mathrm{M})$, as first described by Wadsworth (1927). The former solution is the one now in general use. The experiments which we wish to report in summary support the views of Maclagan, of Varley, and of Ducci, but we have

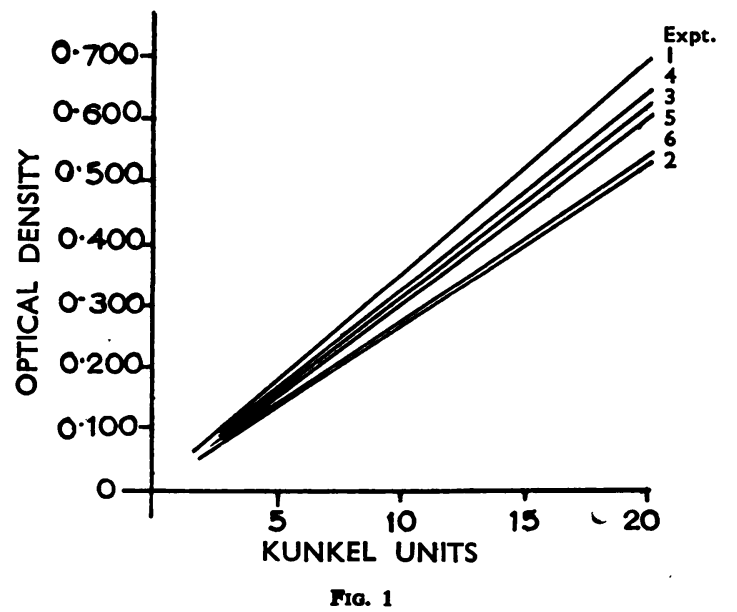

been able to define more clearly the conditions under which reproducible optical density readings can be obtained.

\section{Materials}

$1.15 \% \mathrm{BaCl}_{2} .2 \mathrm{H}_{2} \mathrm{O}$ (Anala R) solution.

$0.2 \mathrm{~N} . \mathrm{H}_{2} \mathrm{SO}_{4}$ (AnalaR).

\section{Experiments and Results}

Volume and Order of Mixing the Reagents.-Three millilitres of $1.15 \% \mathrm{BaCl}_{2} .2 \mathrm{H}_{2} \mathrm{O}$ solution may be mixed with $97.0 \mathrm{ml}$. of $0.2 \mathrm{~N}$. $\mathrm{H}_{2} \mathrm{SO}_{4}$ in many ways. After agitation, the optical density was read immediately on a "unicam" SP 600 spectrophotometer at $650 \mathrm{~m} \mu$, using a $10 \times 10 \times 45 \mathrm{~mm}$. cuvette, against a control of glass-distilled water. The figure shows the mean results of six experiments. These are:

Experiment 1.-Dry flask $+3.0 \mathrm{ml}$. $\mathrm{BaCl}_{2}$ solution + made up to $100 \mathrm{ml}$. with $0.2 \mathrm{~N}$. $\mathrm{H}_{2} \mathrm{SO}_{4}$. Mean O.D. of 19 results $=0.702$.

Experiment 2.-Flask rinsed with $0.2 \mathrm{~N} . \mathrm{H}_{2} \mathrm{SO}_{4}$ and drained $+3.0 \mathrm{ml}$. $\mathrm{BaCl}_{2}$ solution + made up with $0.2 \mathrm{~N}$. $\mathrm{H}_{2} \mathrm{SO}_{4}$. Mean O.D. of 15 results $=0.538$.

Experiment 3. $-10.0 \mathrm{ml}$. $0.2 \mathrm{~N} . \mathrm{H}_{2} \mathrm{SO}_{4}+3.0 \mathrm{ml}$. $\mathrm{BaCl}_{2}$ solution + made up with $0.2 \mathrm{~N}$. $\mathrm{H}_{2} \mathrm{SO}_{4}$. Mean O.D. of two results $=0.623$.

Experiment 4. $-20.0 \mathrm{ml} .0 .2 \mathrm{~N}$. $\mathrm{H}_{2} \mathrm{SO}_{4}+3.0 \mathrm{ml}$. $\mathrm{BaCl}_{2}$ solution + made up with $0.2 \mathrm{~N}$. $\mathrm{H}_{2} \mathrm{SO}_{4}$. Mean O.D. of four results $=0.648$.

Experiment 5. $-40.0 \mathrm{ml} .0 .2 \mathrm{~N} . \mathrm{H}_{2} \mathrm{SO}_{4}+3.0 \mathrm{ml}$. $\mathrm{BaCl}_{2}$ solution+made up with $0.2 \mathrm{~N}$. $\mathrm{H}_{2} \mathrm{SO}_{4}$. Mean O.D. of two results $=0.618$.

Experiment 6. $-80.0 \mathrm{ml} . \quad 0.2 \quad \mathrm{~N}$. $\mathrm{H}_{2} \mathrm{SO}_{4}+3.0 \mathrm{ml}$. $\mathrm{BaCl}_{2}$ solution + made up with $0.2 \mathrm{~N}$. $\mathrm{H}_{2} \mathrm{SO}_{4}$. Mean O.D. of two results $=0.549$.

\footnotetext{
*Present address: Pathology Department, The University and
} 
Thus strict attention must be paid to the method of preparation of the standard suspension by mixing the reagents in a given order.

The Rate of Mixing.-Two $3.0 \mathrm{ml}$. pipettes were selected because of obvious differences in the sizes of the orifices at their tips. By using a standardized procedure it was shown that the rate of adding $\mathrm{BaCl}_{2}$ solution to a $50.0 \mathrm{ml}$. pool of $0.2 \mathrm{~N}$. $\mathrm{H}_{2} \mathrm{SO}_{4}$ and making up to the $100 \mathrm{ml}$. mark with $0.2 \mathrm{~N}_{\text {. }} \mathrm{H}_{2} \mathrm{SO}_{4}$ made no difference to the optical density reading.

Temperature of the Reaction-The procedure was repeated, not only at room temperature $\left(18^{\circ} \mathrm{C}\right.$.), but at $37^{\circ} \mathrm{C}$., at $56^{\circ} \mathrm{C}$, and at $100^{\circ} \mathrm{C}$., the flasks with their contents being continually agitated during mixing, and then cooled thoroughly under running cold water so that the flask and contained fluid were restored to their normal dimensions before being filled to the $100 \mathrm{ml}$. mark with $0.2 \mathrm{~N}$. $\mathrm{H}_{2} \mathrm{SO}_{4}$. The O.D. readings were $0.680,0.640,0.520$, and 0.445 respectively at the above temperatures.

The temperature at which the reaction is carried out is as important as the order in which the reagents are added to the flask.

The Effect of Digestion.-The suspensions produced in experiments 1-6 above were digested at room temperature for 24 hours (Vogel, 1951), and the optical densities were read again after thorough resuspension. On the whole there was no consistency between the first and second readings.

\section{Discussion}

Our experiments show that there is great variability in the optical density readings, depending on the method employed. The two main sources of error are (1) the order of mixing the reagents, and (2) the temperature at which the main reaction is carried out. The reason for the variations is the simultaneous precipitation of barium chloride which is incorporated on the surface of the barium sulphate molecule (Vogel, 1951).

Protein graphs in constant use in this laboratory, and prepared by direct correlation of protein values with optical density values, show that the mean optical density reading for $100 \mathrm{mg}$. protein per $100 \mathrm{ml}$. at $650 \mathrm{~m} \mu$, i.e., 10 Maclagan units or 20 Kunkel units, is 0.656 . The following method produces a standard barium sulphate suspension with this optical density.

Method of Preparing Standard Barium Sulphate Suspencions.-Take a dry 100-ml. volumetric flask. Place $50 \mathrm{ml} .0 .2 \mathrm{~N}$. $\mathrm{H}_{2} \mathrm{SO}_{4}$ in it and place this in a $37^{\circ} \mathrm{C}$. water-bath until this temperature is reached by the sulphuric acid. While still in the bath, add $3.0 \mathrm{ml}$. of $1.15 \% \mathrm{BaCl}_{2} .2 \mathrm{H}_{2} \mathrm{O}$ solution to the flask with gentle agitation. After 10 to 15 sec. remove the flask and cool it with its contents under cold running water, meanwhile continuing the gentle agitation. Once completely cool, top up to the $100 \mathrm{ml}$. mark with $0.2 \mathrm{~N}$. $\mathrm{H}_{2} \mathrm{SO}_{4}$. Insert the stopper and invert the flask several times. Read the optical density of this barium sulphate suspension against glass-distilled water as a control in a "unicom" SP 600 spectrophotometer at $650 \mathrm{~m} \mu$.

Results.-The mean of 11 results is 0.663 (scatter 0.630-0.709), and this involves the use of two different batches of stock reagents. The scatter is now one-third of the overall scatter of the six experiments summarized in the figure.

Finally, the variabilities of standard barium sulphate suspensions described in this papr in no way influence the fundamental theorie of the thymol turbidity test (Maclagan, 1944), the zinc sulphate test (Kunkel, 1947), or the rapid fibrinogen method (Stirland, 1956).

We wish to express our gratitude to Dr. A. D. T. Govan, Director of Research, for his encouragement and guidance during this research.

The work reported is part of that covered by a grant from the Dr. David Foulis Memorial Fund to one of us (J. F. B.).

\section{REFBRENCES}

Ducci, H. (1947), J. Lab. clin. Med., 32, 1266

Kunkel, H. G. (1947). Proc. Soc. exp. Biol. (N.Y.), 66, 217. Ley, A. B., Lewis, J. H., and Davidson, C. S. (1946). 'J. Lab. clir. Med., 31, 910 .

Maclagan, N.' F. (1944). Brit. J. exp. Path., 25, 234.

-(1951). In Recent Advances in Clinical Pathology, 2nd ed., p. 155. Ed. S. C. Dyke. Churchill, London.

Shank, R. E., and Hoagland, C. L. (1946). J. biol. Chem., 162, 133. Shank, R. E., and Hoagland, C. L. (1946)

Varley, H. (1958). Practical Clinical Biochemistry, 2nd ed. Heinemann, London.

Vogel, A. I. (1951). A Text-book of Quantitative Inorganic Analysis, 2nd ed. Lonemans, Green, London.

Wadsworth, A. B. (1927). Standard Methods of the Division of Laboratories and Research of the New York State Department of
Health. Williams and Wilkins, Baltimore; p. 625. Quoted by Shank and Hoagland. 